\title{
LEGISLATION ON THE JUDICIARY: FANTASY LAW OR PROGRAMMED EXPECTATIONS?*
}

\author{
By ThIERRy G. Verhflst
}

African States agree on the necessity of living under the Rule of Law. All their Constitutions (with the sole exception of that of Tanzania) ${ }^{1}$ contain passages to that effect and Statesmen have of ten affirmed their determination to uphold the fundamental liberties of the citizens ${ }^{2}$. There also exists a consensus about the role which the judiciary has to play in that respect. Good judges are seen as a necessary bulwark against the forces which threaten individual liberties and the dignity of the citizens. Thus, the Constitutions of the French-speaking African countries all stipulate that the judiciary is the guarantor of the individual's rights ${ }^{3}$. Many provisions of the Constitutions of English-speaking Africa are based on the same principle. The Constitutional Commission for Ghana stated quite clearly ${ }^{4}$ :

"It is our considered view, a view which is happily shared by all Ghanaians, that the Law Courts of Ghana shall be the custodian and bastion of the liberty and dignity of Ghanaians, the guardian of the Constitution, in short, the citadel of justice. The independence of judges is an essential prerequisite to the attainment of this objective, and it can be achieved only under certain conditions."

The determination to ensure the high calibre of the judiciary is not only found in States which generally adhere to the political philosophy and legal mechanisms inherited from Western colonial powers. Some of the most deliberately socialist States share this conviction. They may disagree about the interpretation to be given to the principle of separation of powers and the independence of the judiciary, but still adhere to the general tenet that the judiciary has a special role to play and that therefore its members need special protection. Thus, the Algerian Constitution affirms the principle of an independent judiciary but its Minister of Justice points out that ${ }^{5}$ :

"Même si l'Algérie s'engageait solennellement à garantir le magistrat dans l'exercice de sa profession, elle ne pouvait au plan des principes reconnaître à ce magistrat un véritable droit contre la société. Non que le magistrat ne soit pas indépendant, il l'est dans la mesure où son action ne va pas à contre-courant de l'évolution politique et économique de l'Algérie."

\footnotetext{
* This article includes revised and up-dated extracts from two background pape's presented by the author at the Conference of African Jurists on African Legal Process and the Individual, sponsored by the U. N Economic Commission for Africa in Addis Ababa, in April 1971.

1 The Tanzanian Constitution does not contain a Bill of Rights. Yet, this does not reflect any negative attitude towards fundamental liberties in that country. It should rather be ascribed to a certain scepticism towards general principles. The Tanzanians' concern for protection of Humar Rights is quite vivid, as is illustrated, among other things, by the institution of an Ombudsman. See A. M. JacomyMillette, "The Ombudsman in Africa", in T. G. VERHELST, Legal Process and the Individual, African Source Materials, p. 178, Centre for African Development, Addis Ababa, 1972

2 T. G. VERHELST and Z. B. PLATER, "Constitutional Guarantees of the Individual", in T. G. VERHELST, op. cit., p. 9.

3 Constitutions of Mauritania, Art. 49, Rwanda, Art. 101 and Guinea, Art. 37.

4 The Proposals of the Constitutional Commission for a Constitution for Ghana, 1968 No. 502.

5 Constitution of Algeria, Art. 62 and M. BEDJAOUI, "La nouvelle organisation judiciaire en Algérie" Revue Juridique et Politique, No. 4, Octobre-Décembre 1969, p. 526 et seq. This text may be translated as follows: ". . Even when Algeria undertook solemnly to protect a judge in the exercise of his office, it could not, in principle, give judges a right against society. This does not mean that the judge is not independent; he is, in so far and to the extent that his act is not harmful to the political and economic development of Algeria"'.
} 
This concept is faithfully reflected in the article of the Algerian Constitution which proclaims that in the exercise of their duties judges are to obey the interest of the socialist revolution.

Tanzania's adherence to the Rule of Law is equally clear. President Nyerere leaves no doubt about it, as it appears from the following address to a Conference of Judges; it is however noteworthy that he insists on the proper meaning to be given to the independence of the judiciary ${ }^{6}$ :

"Judges are, and must be nothing less than the buttress wall supporting the individual justice for which our people struggled when they fought for national independence... There is a separate hierarchy and system of command for the judiciary, and once a man is appointed it is extremely difficult to displace him. These things are intended to help secure impartiality. But they must not do more. They must not lead to the belief that a Judge can be, or should be, 'neutral' on the basic issue of our society... Their interpretation must be made in the light of the assumptions and aspirations of the society in which they live."

At the 1971 Conference of African Jurists on "Legal Process and the Individual", a number of participants voiced their opposition to the principle of independence of the judiciary. This principle, they observed, was of Western origin, and contrary to traditional African legal concepts. Public Law in traditional Africa was characterized by unity, not by separation of powers, and experience proved that there was nothing in that system to prevent safeguarding genuine impartiality in the performance of judicial functions. To these speakers, this principle is not only contrary to African tradition but also to present-day realities and needs of the African continent. New States in process of development would need co-operation on the part of all authorities if development policies are to be successful and squandering of efforts to be avoided. It would indeed be harmful to the stability and development of a country if its magistrates assumed the right to oppose its leaders' social and economic policy on the pretext of judicial independence? ${ }^{7}$. No doubt, a balance must be struck somewhere between subservience of judges to political and administrative authorities - a situation most prejudicial to individual liberties - and total irresponsiveness of the judges to their country's needs and efforts. Be that as it may, all agree that judges have an important role in society.

Although there is an almost universal consensus in Africa as to the high standards to be set for the judiciary, the actual situation is reputed to be less than satisfactory. Many participants to the latest Conference of African jurists agreed that there exists a "crisis of justice" in Africa". There are, first of all, blatant violations of the Rule of Law, such as those which have been reported in countries such as Dahomey, the then Congo-Kinshasa, Zanzibar, Burundi or Uganda. Yet, they are altogether exceptional occurrences and should certainly not be considered as typical of African judicial practice. However, it remains true that almost everywhere, cases are reported of more or less gross denials of justice. Reports of judges making decisions in violation of the law are too many to be ignored.

$6 \mathrm{~J}$. K. NYERERE, Freedom and Socialism, A Selection from Writings and Speeches 1965-67, Oxford University Press, Dar es Salaam, 1969, p. 110 and 112.

7 T. G. VERHELST, op. cit., p. 355 et seq.

8 This was the 1971 Conference on African Legal Process and the Individual organized by the Economic Commission for Africa in Addis Ababa. See T. G. VERHELST, op. cit., p. iv. 
Sometimes, it is their lack of professional competence that is pointed to. Many judges simply are ignorant of the rules and procedures they are supposed to apply. Sometimes also, it is the judges' excessive subservience to powers that be which is reported. They are yielding too often to pressures from political or administrative authorities. Again it is sometimes their moral integrity that is put into question as well as the impartiality of their decisions. Certainly, these probblems are not unique to Africa. They are found everywhere, in varying degrees. The object of this paper is not to describe the shortcomings of the African judiciary but rather to inquire into the statutory provisions which have been enacted, in each independent African State ${ }^{9}$, regarding the judiciary. The analysis of these statutes will enable us to determine whether the African States have seriously tried to implement in their legislation the lofty principles on the Rule of Law and the role of the judiciary which they officially proclaim. Finally, we will make some observations on the ability of legislation to model reality and achieve the aims for which it has been enacted.

This inquiry into the legislation pertaining to the African judiciary will revolve around three questions, which correspond to the three major shortcomings reported above:

1) do the statutes require a certain level of professional qualification from the judges?

2) do they guarantee the judges' independence in the face of political and administrative interference?

3) do they set moral standards for the judges and how do they seek to uphold them?

First of all, we shall have to review rules governing those judges who belong to the ordinary court structure. Thereafter, we must turn to the members of courts and tribunals which have special competences: customary law courts, administrative courts, extraordinary criminal tribunals, etc.

\section{Judges in the ordinary courts}

\section{a) Professional qualification, guarantee of technical competence}

The quality of justice administered in a particular country will depend in a large respect on the judge's actual knowledge and understanding of the law. It is not only irksome, but obviously also prejudicial to due process of law, to have to fight one's case before a judge who fails to grasp the legal intricacies of a particular problem. The lack of professional qualification on the part of the judges is not an easy problem to solve, however. In many African countries, trained manpower is still a relatively scarce commodity. When a State disposes of a handful of lawyers only, there are many good reasons to put them to work in key administrative jobs rather than in courts. Thus, out of the fourteen lawyers to be found in Rwanda, only four have been assigned to the courts. All the others work in Ministries and important State agencies. Similarly,

\footnotetext{
9 Countries under colonial rule, or governed by a minority regime, are not dealt with in this paper. Basic principles of the Rule of Law are openly flouted in these areas. The emphasis here lies on efforts on the part of the new African States to set up a judiciary which would correspond to their declared interest in upholding the Rule of Law, and acquiring a judiciary of high calibre.
} 
Ethiopia's young law graduates are overwhelmingly hired by Ministries and only rarely are they appointed as judges. It is therefore worth inquiring what requirements are set to be appointed as a judge. We shall see that, except for lower courts, the requirements are very high.

In French-speaking Africa only those candidates holding a degree in law or its equivalent are recruited for the judiciary ${ }^{\mathbf{1 0}}$. The candidates must then sit a qualifying examination. Specialized schools, e. g., the Malagasy Institut d'Etudes Judiciaires runs preparatory courses for this examination. This is normally followed by two years of professional training. These training programmes are sometimes given by schools as in Ivory Coast, yet in some cases they are run by the courts themselves ${ }^{11}$. Another standard of recruitment is based on professional experience. Candidates are recruited from within the legal profession: law professors, lawyers, solicitors ${ }^{12}$, etc. and holders of a doctorate in law ${ }^{13}$. Under Zafrian legislation only those judges who have served at least three years in a post will be eligible for promotion. This law is important from the point of view of its guarantee of professional experience, and its limiting effect on rapid, but sometimes tainted, promotion.

In English-speaking Africa, the method of recruitment and the professional standards reflect the English system. In contrast to the French system, young jurists are not trained to be career judges, but judges are appointed from among practising lawyers. This concept is expressed in several constitutions. In Ghana, for example, to be appointed to the Bench of any of the three higher courts, one must have the right to practice in any of the civil or criminal courts in Ghana or any country having a similar legal system, so recognized by the Judicial Council. In addition, several years' practice as a barrister is necessary - 15, 12 or 10 for appointment to the Supreme Court, the Court of Appeal, or the High Court respectively ${ }^{14}$. In Kenya and Uganda the experience required for appointment to the courts may be that of the Bench or that of the Bar ${ }^{\mathbf{1 5}}$. In Ethiopia, the Constitution merely stipulates that judges are to be experienced in the sphere of law which they will be called to apply ${ }^{\mathbf{1 6}}$.

The general principles of recruitment have had to be modified by several countries. When it became necessary to africanize the Judiciary, examples of this were found even at the level of the higher courts. In Burundi and in Rwanda, for example, africanization was speedily effected without much thought having been given to the qualification of the judges ${ }^{17}$. This solution is most likely to satisfy the aspiration of independence, but may prove unfortunate as far as respect for the Rule of Law is concerned.

Where the lower courts are concerned, the dearth of professional magistrates is even more accutely felt than in higher courts. It is common knowledge that two different approaches to the organization of the judiciary are to be found. Some countries have maintained a dual judicial structure. In this case, the or-

10 Cameroon, Federal Act No. 205 of April 28, 1966; Dahomey, Act No. 5 of April 20, 1965; Zaïre, Act No. 68-246 of July 10, 1968.

11 Senegal Act No. 47 of November 9, 1960; Gabon Act No. 23-PR. M. J. of March $22,1963$.

12 Mauritania, Act No. 014 of January 18, 1963; Zaïre Act 68-246 of July 10, 1968.

13 Central African Republic Act No. 367 of February 1, 1963 ; Zaïre Act of 1968 supra.

14 Constitution of Ghana Art. 120.

15 Constitution of Kenya, Art. 61, and of Uganda, Art. 84 and 89.

16 Constitution of Ethiopia, Art. 111.

$17 \mathrm{~J}$. GILISSEN et J. VANDERLINDEN, “Essai de synthèse” in J. GILISSEN, L'organisation judiciaire en Afrique noire, Etudes, Ed. de l'Institut de Sociologie, Bruxelles, 1969, p. 41 and T. G. VERHELST, La legislation rwandaise en dix années d'Indépendance, Nyabisindu 1972 (mimeo; to be published). 
dinary court structure applies the so-called written law, while the other applies customary law. These are tribunals with special competences and it is to be expected that rules relating to their judiciary differ from those applicable to ordinary courts (cf. infra sub II: judges in special courts and tribunals). Yet, other countries have (more or less) unified their court structure. In these countries, there is only one set of courts having competence in all fields of the law, both customary and written ${ }^{18}$. And yet the difference between the unified and separate structures is not as important as one may believe. Indeed, in spite of their desire to modernize their legal system, the countries which have established a unified court structure (e. g., Zaïre, Madagascar, Kenya, Somali, Ghana) nevertheless have to be satisfied, in most cases, with the same lay magistrates who sat in the former customary courts, or with lower members of the legal profession (traditional chiefs, elders, etc).

Thus in French-speaking States, a degree in law is no longer necessary for those candidates to the lower courts who served as clerks to former courts, provided that they are successful in the qualifying examination ${ }^{19}$. In Dahomey, the composition of the first-degree courts for written law and of customary courts, which have been integrated at the bottom of the hierarchy of courts, has not been modified. In Senegal, the Cadi of the Moslem courts of former French West Africa has been skilfully incorporated into the corps of Justices of the Peace. A similar solution was found in Mauritania. Noteworthy however is that, in this country, the Moslem law judges are chosen from among the best jurists of the Malekite code (Islamic Law) ${ }^{20}$. Lower courts are often composed of district officers or other members of the executive branch (cf. infra: composition of the courts). Although these officials have no formal legal training, they have acquired an experience in judicial matters. In Zaïre, the new justices of the peace, who are only competent to deal with minor criminal and civil cases and with customary law cases must not hold a legal degree.

In English-speaking Africa, the high standards set for appointment to the superior courts are not automatically applicable to the lower courts. The rules of recruitment for these courts are laid down, in Ghana by the Chief Justice on the advice of the Judicial Council21, in Kenya by the Judicial Service Commission ${ }^{22}$ and in Uganda by the President of the Republic, on the advice of the Judicial Service Commission ${ }^{23}$. Thus, the lower courts of Kenya are still composed in part of former judges of the "African Courts"24. In other countries, judges trained in European law are assisted by assessors versed in customary law ${ }^{25}$. It does not seem possible that judges of the lower courts could, in the short run, acquire the same qualifications as their colleagues in the higher courts, such as University training in law, or long legal experience. But at least efforts should be made to ensure that they possess basic professional skills. Lower court judges

\footnotetext{
18 This policy of integration is in keeping with conclusions of the African Conference on the Rule of Law,
which recommended that all national law, traditional or modern, should be administered by the ordinary courts of the land. African Conference on the Rule of Law, Lagos (Nigeria), January 3rd-7th, 1961. A Report of the Conference, Geneva, 1961.

$19 \mathrm{Cf}$. M. JEOL, La Réforme de la justice en Afrique Noire, p. 96, Pédone, Paris, 1963.

20 Mauritania, Act. 014 of January 18, 1963

21 Constitution of Ghana, Art. 20.

22 Constitution of Kenya, Art. 69.

23 Constitution of Uganda, Art. 91

$24 \mathrm{Cf}$. GHAI and McAUSLAN, Public Law and Political Changes in Kenya, Nairobi, Oxford University Press, 1970, p. 372

25 Tanzania, Magistrates Courts Act No. 55, 1963. In exceptional cases, the assessors are entitled to vote. This is the case in Mali.
} 
who have been appointed a long time ago, during the colonial occupation, do have such skills. What they lack in theoretical training they have gained through a long career in practice. But many of these particular judges are now close to retirement-age and no sufficient attention seems to have been paid by a number of African States to ensure their adequate replacement. Because there is a tendency to follow too closely the European educational system as the only valid one, a number of States have done no more than setting up Law Schools at University level. However, failing to set up legal training institutions at levels inferior to the licence or LL.B. degree and capable of handling in relatively short time a large number of students, these countries may soon be faced with vacant judgeships at the lower court level and nobody adequately trained to fill them. They might then have to appoint judges totally devoid of any professional or legal ability. It should be pointed out that some countries have not ignored this problem. Thus, Rwanda has already created a legal training centre for lay magistrates. Its aim is to provide practising but unqualified magistrates with technical training, based on legal practice ${ }^{26}$. In Zaïre a school for justices of the peace is planned. A few English-speaking countries have also taken steps in that direction. Thus, Uganda and Kenya have organized training courses for lay magistrates ${ }^{27}$. In Tanzania, this is handled by the Institute of Development Management.

\section{b) Independence of the judiciary}

\section{i) The principle}

Nearly all the constitutional texts of African States devote 28 at least some articles to the independence of the judiciary. Some constitutions use the simple term "Judicature" (Kenya), "Judiciary" (Egypt), or "Courts" (Nigeria), while others speak of an "Autorité judiciaire" (Senegal, Ivory Coast, Gabon) or a "Pouvoir judiciaire" (Zaïre, Mali, Ethiopia) or "Administration de la justice" (Equatorial Guinea) or "Judiciary Department" (Liberia). This difference of terminology does not correspond to any intended difference in the degree of independence of the judiciary. The extent of this independence is to be found in articles of the constitutions and in legislative texts, particularly those dealing with the professional rules governing the members of the judiciary. These rules differ considerably in accordance with the kind of courts: members of ordinary courts are much better protected against all sorts of pressures than are members of special jurisdictions. Let us then inquire into the procedure of the appointment of judges (ii), the composition of the courts (iii), and the irremovability of judges (iv), in order to find out how the principles of independence are implemented in them.

Several constitutions proclaim that judges in the exercise of their office are subject only to the authority of the law ${ }^{29}$. Thus the Ghanaian Constitution states that

26 The Centre national de formation judiciaire at Nyabisindu started in 1970. Cf. T. G. VERHELST, La législation rwandaise..., op. cit.

27 Noteworthy are the multifarious activities (short and long courses for magistrates, law reports, etc.) of the Law Development Centre at Kampala (Uganda), a centre started in 1968. See this Centre's Annual Reports.

28 Not, however, the Constitution of the People's Republic of the Congo.

29 Constitution of Ethiopia, Act. 110, Guinea, Art. 35 and Egypt, Art. 152. 
the judiciary is subject to the Constitution and no other authority. The executive is explicitly excluded from all final judicial action ${ }^{30}$. These clauses express the traditional liberal doctrine of the separation of powers. The result is that the executive cannot give binding instructions to the judge concerning the interpretation of the law, or issue injunctions concerning the stand he should take on any matter sub judice. Still further, the judge should not be subject to any pressure, as a result of any act done during the exercise of his office ${ }^{31}$. Most of the Constitutions of the French-speaking countries state that the President of the Republic is the guarantor of the independence of judges and is assisted by the Conseil supérieur de la magistrature (The Upper Council of the Judiciary) $)^{32}$. The value of instituting the Head of State as guarantor of the independence of the judiciary is doubtful indeed. It is a principle inspired by French constitutional law but in France the Head of State is distinct from the head of government, and it is therefore possible for him, at least in theory, to act as an impartial umpire and to protect the judiciary from undue pressure. This is not the case in Africa, however, where the Head of State is generally also the head of government. The African Head of State is even less impartial an umpire because he often is, besides head of government, the leader of the single party or at least the major party.

\section{ii) Appointment of judges}

The method of appointing judges creates a thorny problem from the point of view of the independence of the judiciary. The solution might be that in law or in practice there should be some degree of co-operation (or at least consultation) between the judiciary and the authority actually making the appointment.

In French-speaking Atrica this is the solution which has been more frequently adopted for ordinary courts. Indeed, judges in those courts are appointed by the President of the Republic ${ }^{33}$. But this infringement of the principle of the separation of powers is mitigated by the close relations which exist between the executive and the judiciary. Their co-operation is mainly exercised within the Conseil supérieur de la magistrature. This body submits names of judges for appointment by the President of the Republic ${ }^{34}$. Sometimes, it merely gives an opinion on the proposals made by the Minister of Justice ${ }^{35}$. The Conseils supérieurs de la magistrature vary in composition. They are normally presided over by the Head of State or a member of the Council of ministers (in principle the Garde des Sceaux, or Minister of Justice) and include, besides the ex officio member or members (namely the Chief Justice), either judges only (who are often elected rather than nominated), or judges and well-known personalities such as representatives of the national assembly and the President of the Republic ${ }^{36}$.

\footnotetext{
30 Constitution of Ghana, Art. 102.

31 Constitution of Ghana, Art. 102 (9) and 120 (2).

32 Constitution of Ivory Coast, Art. 59, Chad, Art. 63 and Rwanda, Art. 101.

33 Constitution of Niger, Art. 61; Tunisia, Art. 54 and Cameroon, Art. 32.

34 Cameroon, Act No. 55 of May 7, 1960.

35 Senegal, Act No. 60-16 of September 3, 1960; Ivory Coast, Act No. 61-202 of June 2, 1969.

36 The Conseil supérieur de la magistrature does not participate in the nomination of members of the Public Prosecutor's office. Its role is limited to that of appointing judges to the Bench, in order to guarantee their independence from the executive. The members of the Department of Public Prosecution are appointed like other officials, without any special procedure.
} 
In English-speaking Africa, a distinction is generally made between three categories of judges. The Chief Justice is often appointed directly by the President of the Republic alone. The other members of the higher court or courts are appointed by the President of the Republic in agreement with the Judicial Service Commission ${ }^{37}$ or the Judicial Council ${ }^{38}$. The judges of the lower courts are subject to different rules of appointment. In Uganda, they are appointed by the President of the Republic, in agreement with the Judicial Service Commission. These rules, however, do not apply to all the courts. Parliament decides their application ${ }^{39}$. In Kenya, the judges of the lower criminal courts and those who serve exclusively in civil courts, must be appointed by the Judicial Service Commission (which may however delegate its power). Parliament also has the power of appointing judges to exercise the same functions as those exercised by the Commission ${ }^{40}$. In Ghana, these judges are appointed by the Chief Justice in consultation with the Judicial Council, and in agreement with the President of the Republic ${ }^{41}$. The Judicial Service Commission (the Judicial Council in Ghana) varies in composition as well, as it is the case for the French Supreme Councils of the Judiciary. In Kenya it is made up of two judges from the higher courts who are appointed by the President of the Republic and the Chairman of the Public Service Commission ${ }^{42}$. In Uganda, a third magistrate is to be found instead of this official ${ }^{43}$. In Ghana, the Judicial Council is made up of the Chief Justice, two judges (of the Court of Appeal and High Court), the attorney-general and three lawyers and a lay member, appointed by the President of the Republic ${ }^{44}$. Things developed differently in Nigeria. The Republic Constitution provided for judges to be appointed by the President or Regional Governor acting in accordance with the advice of the Prime Minister or the Regional Premier as appropriate. This Constitution did away with the Judicial Service Commission which had been established pursuant to the 1960 Constitution and which gave advice to the executive on the appointment of judges. Since the military takeover, a new body, the Advisory Judicial Committee has been set up. It advises the Supreme Military Council on the appointment of judges ${ }^{45}$.

As a whole, it does not seem that the procedures for the appointment of judges in Africa involve clear threats to their future independence. The safeguards set forth by constitutions and statutes can generally be said to be satisfactory.

\section{iii) The composition of courts}

Ordinary courts are, as a rule, staffed by members of the judiciary. However, although the principle of the independence of the judiciary with regard to the other powers is generally proclaimed, it is sometimes found that members of the executive sit in the ordinary courts. Thus, in Swaziland and Botswana, the

37 Uganda, Kenya, cf. supra.

38 Ghana, cf. supra.

39 Constitution of Uganda, Art. 91.

40 Constitution of Kenya, Art. 61.

41 Constitution of Ghana, Art. 121.

42 Constitution of Kenya, Art. 68.

43 Constitution of Ugarida, Art. 90.

44 Constitution of Ghana, Art. 119.

45 Cf. S. D. ADEBIYI, “The Executive and the Judiciary - the Nigerian Experience”, in T. G. VERHELST,

Legal Process and the Individual..., op. cit., p. 159 et seq. 
district commissioners, senior district officers and district officers sit in the lower courts $^{46}$. The majority of district magistrates in Kenya are still civil servants (District Commissioners, District Officers) ${ }^{47}$.

In Chad, the senior district officers are justices of the peace ${ }^{48}$. In Madagascar the police courts are administered by senior district and district officers. In the Central African Republic, the senior district officer is chairman of the first degree court ${ }^{49}$. This situation does not meet the stated requirements with regard to independence of the judiciary. Nevertheless, there are many who believe that it is the only practical solution, on the one hand, because of the dearth of judges in the new African States (cf. supra: professional qualifications) and on the other, because of the extensive territories to be administered. To reject this system would be to deprive the population living in the most remote parts of the country of justice. A former Minister of Justice of Madagascar said in this respect that his Government considered that justice even though impugnable "was better than no justice at all"50. It is significant in this respect that the draftsman of the Constitution of Zaïre (then the Democratic Republic of Congo), himself recognizing the necessity for this equilibrium between the separation of powers and the availability of judges, excluded from the clause in the Constitution of 1967, concerning the independence of the judiciary, this stipulation found in the Constitution of 1964, viz: "Under no circumstances may the judicial power be exercized by the legislative or executive bodies." In fact only very few civil servants still sit in the lower courts of Zaïre. Ghana chose the happy middle way, a solution which reconciles the principles of an independent judiciary with the imperative of practice. Its Constitution stipulates that no organ of the executive may exercise final judicial authority ${ }^{51}$. In other words the decisions of the lower courts, or other judicial bodies in administrative affairs, would in all cases be subject to appeal to the ordinary courts of law.

Whatever practical reasons may be advanced in favour of them, exceptions to the principle of an independent judiciary require critical examination. This is all the more so that it is not altogether clear whether the countries implementing such exceptions regard them as no more than temporary measures. However, the danger of such exceptions should not be over-emphasized, as they are met in lower courts only. There is always a possibility of appeal to a higher court. And these courts are, as we know, generally staffed by independent and professional judges ${ }^{52}$.

\section{iv) Irremovability}

As is aptly stated in the conclusions of the Congress of Jurists of New Delhis3, the principle of irremovability of judges and the security of tenure until death (or until a retiring age fixed by statute is reached), is an important safeguard of

\footnotetext{
46 Swaziland and Botswana, Subordinate Courts Proclamation, 1958.

47 Cf. GHAI and McAUSLAN, op. cit., p. 372.

48 J. BRAHIM SEID, "L'organisation de la justice au Tchad" Revue Juridique et Politique, op. cit., p. 603.

49 F. GON, "L’organisation judiciaire centrafricaine en matière civile", Revue Juridique et Politique, op. cit., p. 552.

50 Ramangasoavina, "L'organisation judiciaire malgache en matière pénale”, Revue Juridique et Politique, op. cit., p. 787.

51 Constitution of Ghana, Art. 102

52 Indeed some countries even provide for a double appeal (Ethiopia, Rwanda) when the first judgement has been rendered by a lower court.

53 These conclusions were reaffirmed by the African Conference at Lagos.
} 
the Rule of Law. Although it is not impossible for a judge appointed for a fixed term to assert his independence, he is subject to greater difficulties and pressure, particularly if he is seeking re-appointment, than a judge who enjoys security of tenure for his life.

The irremovability of judges from the Bench is explicitly guaranteed in the Constitutions of a number of French-speaking countries ${ }^{54}$, and the majority of these countries make reference to this in the laws concerning the judiciary. Only Algeria and the People's Republic of the Congo make mo mention of it. This principle of irremovability presupposes that judges of the Bench cannot be posted elsewhere, even on promotion, without their consent. In addition to this, the retiring age is fixed by statute, the possibility of dismissal is severely limited, and replacement can only be ordered in the case of ill health resulting in permanent disability, making the performance of his duty impossible. Definite rules concerning a retiring age and dismissal are also found in Englishspeaking countries, mainly in the Constitutions ${ }^{55}$. The retiring age is fixed by statute in Ghana or by Parliament in Kenya and Uganda. The rules concerning dismissal differ according to whether the judge concerned is Chief Justice, a judge of the High Court or a judge of a subordinate court. Dismissal of judges because of mental or physical disability or for serious misconduct is possible. The Republic Constitution of Nigeria provided that a judge could only be removed from office if there were presented to the President (or the Regional Governor) addresses from both legislative houses praying that he be removed. Mention had to be made in the addresses that at least two thirds of the members of the houses had voted in favour of the motion. Under the military regime, this safeguard has been repealed. Removal is simply decided by the Supreme Military Council acting after consultations with the Advisory Judicial Committee.

There are other exceptions to the rules of irremovability, which greatly diminish the practical value of this guarantee. This is the case, for example, with interim appointments. In Senegal, a distinction is made between mere interim appointments within the same court, which are made by the decision of the Minister of Justice after consultation with the head of the court, from those temporary secondments to other posts, in the interest of the service. These depend on the decision of the President of the Republic acting on the advice of the Conseil supérieur de la magistrature. Obviously, in such cases a guarantee against arbitrary detachment is no longer absolute. In Cameroon, a judge can be seconded to another post under the rules applicable on appointment. In the Ivory Coast, the Minister of Justice may, by mere decision, appoint regular magistrates, ad interim, to vacant posts on the advice of the Chief Justice. All these provisions can of course be used only for their specific aims, viz: to guarantee the continuity of judicial activity. As in so many other fields concerning fundamental rights, and the limitations imposed on the executive, experience has shown that their real safeguard lies in the readiness on the part of the executive to sincerely observe them and on the part of the judiciary to resist all attempts to excessively curb their independence. If these attitudes are missing, then these exceptions will constitute most harmful loopholes in the general law.

54 Constitutions of Senegal, Art. 80, Mauritania, Art. 47 and Gabon, Art. 56.

55 Constitution of Ghana, Art. 116, Kenya, Art. 62 and Uganda, Art. 85. 


\section{c) The rules of discipline}

The independence of the judiciary from the other powers is an essential prerequisite of its integrity, but that alone is not enough. More than this, a judge must be unbiased and impartial. Family or religious pressures, attempts of bribery, private relations of any kind, fear of public opinion, even more or less conscious preoccupation with personal problems or personal tendencies, the high tension created by an excited court room, are many of the dangers which constantly threaten the integrity of judges, and against which they should be forearmed. That is the role of the rules of discipline to which they are subject.

In the Constitutions of the French-speaking countries, no mention is made of the rules and disciplinary sanctions of the judiciary, but such rules are clearly laid down in a separate act. In private life, the judge should act in keeping with his status and prestige. Any misdemeanour, lack of tact or dignity in respect of his status, would give rise to disciplinary action. Judicial functions are incompatible with a long list of activities. In the political sphere, participation in politics is expressly forbidden, as well as any outward manifestation of hostility to the principles or the form of government or any untimely act of a political nature. The judicial function is also incompatible with elective office. In the exercise of his office, law and tradition prescribe that his behaviour should reflect the independence and objectivity of a judge. Malagasy legislation expressly prohibits consultations on cases which he has to hear, nor is he allowed to accept gifts from the parties concerned, nor to drink or eat with them. $\mathrm{He}$ may not hear a case if some prejudice opposes him to one of the parties. Still under Malagasy legislation it is recommended that judges who have compromised themselves by their behaviour, should request to be excused from hearing a case ${ }^{56}$. In Cameroon, a judge takes the following oath: "I swear and promise to carry out my functions faithfully and to the best of my ability, to keep all consultations confidential and to conduct myself in keeping with the dignity and loyalty of a judge ${ }^{\text {"57 }}$. Sanctions vary from a mere reprimand to dismissal (with loss of pension rights) and may involve change of office, retirement from certain functions, loss of seniority, demotion, reduction in salary, loss of promotion or immediate retirement. Disciplinary power over judges belongs to the Conseil supérieur de la magistrature.

English-speaking countries have no equivalent to such acts and are faithful to the tradition of common law, leaving the definition of the duties and obligations of judges, and disciplinary sanctions, to practice. The Constitutions go no further than to declare that a judge guilty of misconduct may be dismissed ${ }^{58}$.

It is, of course, important to ensure the independence of the disciplinary body, so that it may be free of political intervention, and thus preserve its freedom of action.

In French-speaking countries the Conseil supérieur de la magistrature is normally responsible for exercising disciplinary power in respect of judges on the Bench. Let us note, however, that the heads of courts supervise to some extent the judges under them and may admonish them and that in some countries the

56 Ramangasoavina, "Le corps des magistrats malgache", Revue Juridique et Politique, op. cit., p. 1172.

57 Cameroon Federal Act No. 66-205 of April 20, 1966.

58 Constitution of Ghana, Art. 110, Kenya, Art. 62 and Uganda, Art. 85. 
Minister of Justice has this authority over the heads of courts themselves (Tunisia, Togo, Cameroon). But the most severe sanctions that can be inflicted emanate necessarily from the Conseil supérieur de la magistrature, after a hearing in which the accused judge is allowed to defend himself. The independent status, which these Conseils normally enjoy, has been mentioned above (Cf. supra: appointment of judges) $)^{59}$.

In some francophonic States it is not the Conseil supérieur de la magistrature which is the disciplinary body for judges. Thus in Tunisia, the disciplinary board is made up only of judges. In Madagascar the disciplinary power is exercised by the general assembly of the Supreme Court, or the Court of Appeal sitting as a disciplinary board.

In English-speaking countries, the competent body responsible for dismissal is also independent. All requests for dismissal are addressed to the President of the Republic. The latter may submit the matter to a tribunal made up of three members appointed by himself (Kenya, Uganda) or by the Judicial Council (Ghana). This tribunal observes normal legal procedure. After consultation their decision is communicated to the President of the Republic who must act accordingly. In the case of the Chief Justice of Ghana, this tribunal is appointed by the President of the Republic after consultation with the State Council and is made up of three members of the Supreme Court and two laymen, who are neither members of the National Assembly nor the State Council. In the case of the Chief Justice of Kenya, the competent tribunal is made up of judges appointed by the Civil Service Commission. As far as judges of the lower courts are concerned, many constitutions of English-speaking countries stipulate that the Judicial Service Commission, acting as a disciplinary body, is the competent authority.

Again, it cannot be said that the statutary law pertaining to these judges fails to correspond to the proclaimed ideals of independence and integrity.

\section{Judges in special courts and tribunals}

There exists a large number of courts with special competences, and whose members are not governed by the same rules as those set forth for the judges of the ordinary courts. It is not the place here to review all of these courts, but only to mention some of the most important ones. We shall deal with the customary law courts, the administrative law courts and some exceptional tribunals in the criminal field, and look into the problem of professional competence, independence and moral integrity.

It has already been mentioned that a large number of African States have kept the dual judicial structure which they had inherited from the colonial period. These countries therefore have special courts, dealing only with customary law, and the rules applicable to the judges of these courts are not necessarily the same as those relating to judges of the ordinary courts. While in the countries with an integrated court system it has not been possible to appoint professional magistrates at all levels, it is a fortiori the same for those countries which have retained separate customary courts. The members of these courts are merely persons acquainted with customary or religious law. This is the case for

59 See text accompanying footnotes nos. $31-33$. 
example in the Gambia, Sierra Leone and the Sudan. In Swaziland, it is merely stipulated that the composition of the customary courts should be based on customary Swazi law ${ }^{60}$. Malawi simply stipulates that the judges of the subordinate courts should be capable and competent ${ }^{61}$. Nevertheless, some countries have tried to institute a more serious method of recruitment. So for example in one of the Nigerian states where, among qualifications required for the Chairman of the customary courts, are an elementary school certificate, ability to read and write English, and adequate experience ${ }^{62}$. Zambia has organized special training courses for lay magistrates. They are handled by the National Institute for Public Administration. Furthermore, customary law judges are often not appointed for life. Obviously, the absence of irremovability for these judges is not necessarily to be ascribed to a desire on the part of the governments to exercise undue pressure on them. Rather, it is a way to allow the dismissal of those judges whose professional performance is unsatisfactory. This appears as a healthy safeguard for any country which wants to gradually improve the technical qualification of its customary law judges. Otherwise, these judges are governed by very much the same rules as their colleagues in the ordinary courts.

Some former French colonies have retained separate administrative law courts. As in France, these specialized courts deal with problems of administrative law. The recruitment of administrative judges leaves much to be desired in Africa. Lacking trained administrative judges, ordinary (non-specialized) judges or halfspecialized civil servants, and to a lesser extent persons with no more than recognized "competence", are used. This lies in sharp contrast with the administrative judge in France who is a civil servant and has above all a wide experience in public law. Through his experience and integrity he guarantees the development of sound administrative law. It may be concluded that systematic recourse to magistrates by the judiciary nullifies any reason for the existence of separate administrative law courts. Furthermore, an excessive use of mere civil servants who are not required to have any genuine legal knowledge is a threat to the guarantee of technical competence ${ }^{63}$. Neither is there much guarantee as to the independence of the administrative law judges. In France they are civil servants but their independence from the executive is well-rooted in tradition and in their own expertise. This is obviously not the case in the new African States. We have seen that the technical competence of the administrative law judge is not particularly high. Furthermore, he is appointed only for a fixed term, and such appointment is made by the head of the executive alone, on the approval of the Minister of Justice. This lack of protection against pressures from the executive is all the more dangerous in that it is the executive who is a party to the cases this judge has to decide upon ...

Various exceptional courts and tribunals in the criminal field have been set up in African States, particularly in French-speaking countries. Again, it is not the place here to review them all ${ }^{64}$. Let us only mention special tribunals set up to try cases of high treason on behalf of a Head of State, Ministers and their accomplices (Hautes Cours de Justice), tribunals created to try all sorts of crimes such as

60 Swazi Courts Proclamation No. 80 of 1950, para. 3.

61 Malawi Courts Ordinance 1958, p. 54 and Courts Amendment Act No, 47 of 1967.

62 Mid-Western State Customary Courts Edict, 1966, s. 6.

63 Cf. JEOL, op. cit.

64 See in that respect, T. G. VERHELST, “Survey of Some Exceptional Courts and Procedures in Criminal Matters", in T. G. VERHELST, Legal Process and the individual . . ., op. cit., p. 82. 
attempt of subversion, armed rebellion, terrorist activity (Cours de Sûreté de l'Etat), and courts with special jurisdiction to deal with "economic crimes" (Guinea's Tribunal Spécial and the Special Tribunal of Zanzibar).

The Hautes Cours de Justice are typically composed of members elected by and from the National Assembly. No particular professional standard is required from these members ${ }^{65}$. In Madagascar the Haute Cour de Justice consists of three justices of the Court of Appeals, and of eight members of Parliament of whom no particular legal training is required ${ }^{66}$. It is obvious that those members are in no way enjoying sufficient protection against political pressure. Much to the contrary, they are very much expected to give politically motivated decisions, and it is likely that they will do so if and when required.

The Cours de Sûreté de l'Etat or their equivalent are sometimes composed of professional judges only ${ }^{67}$. Sometimes they comprise both legally trained judges and ordinary citizens or members of the armed forces ${ }^{68}$. Procedures for appointment are mostly quite summary. Thus the appointment of justices to sit on the Cour de Sûreté d'Etat of Dahomey originates with the Council of Ministers, but is made following approval by the Conseil supérieur de la magistrature. The justices who sit with eight advisors on the Tribunal spécial in the Upper Volta are appointed by the President of the Republic who acts upon nominations submitted by the Minister of Justice, after consultation of the Conseil supérieur de la magistrature. The advisors are chosen by lot from a list of citizens established by the Ministers of Justice, of the Interior and of Security. Judges sitting on the Cours de Sûreté d'Etat generally do not enjoy irremovability. They are appointed for periods ranging from one to five years. The independence of these judges is very limited indeed. Sometimes, the reality of a "political tribunal" is frankly admitted. In Guinea, only representatives of the executive and the legislative branch are seated as judges. Thus, this Guinean court is made up of the President of the National Assembly, the Ministers of Justice and of Defense, and three members of the National Assembly hand-picked by the Head of State. It is clear that such tribunals hardly correspond to the criteria set forth as necessary to ensure legal competence and independence of opinion on the part of their members.

Certain African States have created courts of exceptional jurisdiction to deal with "economic crimes". These non-political courts seem to have been designed on the one hand to protect the public funds and on the other hand, to dispense exemplary justice. Guinea created a Tribunal spécial in 1966 to judge economic crimes, particularly those relative to customs fraud, exchange fraud, fraud in export declarations, and all acts which directly or indirectly "prejudice the marketing of Guinean agricultural products" 69 . This tribunal is composed of the Minister of Foreign Commerce, the President of the Court of Appeals, the two Secretaries of State attached to the Presidency, and a Secretary General. Zanzibar has established a Special Court to try political and economic offenses ${ }^{70}$. The Special Court is composed of not more than 14 members appointed at the discretion of the Pres-

65 Ivory Coast, Constitution, Art. 63-66, Act No. 63-1 of January 12, 1963 and Act No. 59-230 of November 7, 1959; Senegal, Constitution, Art. 85-87; Chad, Constitution, Art. 76-79.

66 Constitution of Madagascar, Art. 18.

67 Ivory Coast, Act No. 63-2 of January 11, 1963; Dahomey, Ordinance No. 69-9 of May 7, 1969 and Niger, Act No. 64-031 of November 2, 1964

68 The Tribunal Militaire Permanent of the Central African Republic is an example of such practice: Ordinance No. $67-39$ of 1967.

69 Guinea, Act 50/AN/660 of February 28, 1966, amended by Act No. 72-67 of April 14, 1967.

70 Zanzibar, Decree No. 16 of 1966. 
ident. Libya set up a Special Court, following the revolution of October 196971. This Court had jurisdiction on all matters submitted to it by the Revolutionary Council as well as cases referred to it by ordinary tribunals and other administrative organs. The members of this Special Court were appointed by the Revolutionary Council itself. They were however obligated to carry out their tasks, "honestly, justly, and impartially".

There is no doubt that a number of the statutes setting up special tribunals in African States fail to correspond to some of the elementary criteria of competence and independence to be expected from judges. In some cases, such infringements on general principles may be explained by the particular political events that have just taken place. Most revolutions anywhere in the world have engendered their special tribunals. Independence of mind or proficiency in the law is certainly not what is then primarily expected from the judges appointed to such jurisdictions. However, the special tribunals which some of the African States have set up do not seem to correspond to any temporary need. Rather, they tend to appear as permanent features of these countries' judicial systems, and as such, constitute a severe threat to the Rule of Law. Quite fortunately, they are not a frequent occurrence in Africa.

\section{Conclusion}

As far as ordinary courts are concerned, statutory law in Africa generally provides satisfactory provisions regarding professional qualification, independence, and integrity of the judges. There are a number of exceptions, but on the whole, it can be said that legislation relating to the judiciary of ordinary courts is quite adequate. Where exceptional jurisdictions are concerned, the picture is certainly not so bright. Administrative courts in French-speaking States hardly seem able to curb abuse of power on the part of the executive. Exceptional tribunals for criminal or economic offenses infringe blatantly on the most elementary principles regarding the independence of the judiciary, let alone regarding its professional competence. Yet, they remain exceptional tribunals and many States have had no resort to them at all.

On the whole, therefore, this survey of statutory provisions relating to the African judiciary does certainly not lead to the conclusion that there is a wanton discrepancy between proclaimed ideals and the way statutes have in fact been drafted. It may still be affirmed that African legislation regarding the judiciary is in line with the proclaimed principles. African legislators have done much to equip their countries with a judiciary of high calibre. And yet, justice is far from perfect. Ignorance, bias and corruption on the part of judges are reported throughout the continent, and governments often interfere in judicial affairs. There is indeed a "crisis of justice" in Africa"2. The conclusions to be drawn from such observations are obvious enough: the laws in the books of ten fail to achieve the objectives for which they have been enacted. Thus Parliament may decide that a University degree in law is required to be appointed a judge but the availability of trained lawyers in the country, or the particular policy of the government towards their allocation, will produce many exceptions to this rule. It may then be alleged, as the Supreme Court of Rwanda did, that force

71 Cf. Revue de la Commission Internationale des Juristes, No. 5, Mars 1970, p. 14.

72 See text accompanying footnote No. 8. 
majeure stands in the way of implementing the $\mathrm{law}^{73}$. A Constitution may proclaim that judges are not to be removed from office, except in the case of grave offense. Yet, the political climate in a particular State may be such that a government finds the decision of a judge irreconcilable with its fundamental political principles and chooses to fire him even if he has applied the law according to his conscience. A set of disciplinary rules may be particularly demanding and violations of them may be drastically punishable under the law. However, a judge's salary may be such that he is unable to resist temptations so that his decisions will favor the powerful or the rich. Thus, budgetary constraints, the (alleged or real) needs of nation-building, the scarcity of manpower are factors which very much determine the extent to which the law will be effectively applicable. These observations corroborate, it would seem, a more general thesis that law is but a fairly weak tool to model reality. The lawyer who likes to think of law in the developing countries as an instrument of social engineering or as a set of mechanisms able to promote development ought to remain modest about the ability of his discipline to achieve much in that respect. Indeed, when law is faced with economic, social or political factors opposed to what it seeks to regulate, it is threatened with failure. Developing countries are thus replete with more or less well-meaning statutes which are too often "fantasy laws"74.

As far as African legislation on the judiciary is concerned, some is probably still closer to fantasy than to reality. Having no chance to be implemented, it merely results in a gap between law and fact. Such a gap is most prejudicial, as it tends to discredit the legal system in the eyes of the people. Other statutes, on the contrary, merely reflect existing conditions and make no effort to induce change. In some cases, these statutes actually institutionalize distasteful practices and procedures which clearly violate the Rule of Law. This is the case with some statutes on Special Tribunals. If some merit is to be found in such legislation, it is sincerity. No efforts are made in it to hide reality behind a screen of lofty words.

Most of the African statutes on the judiciary, however, may well belong to a third category: those which still look a bit too ambitious at the present moment but in fact are merely ahead of their time, and have a reasonable chance of being implemented some day. Given socio-economic and political ${ }^{75}$ conditions conducive to their implementation, they may be successful. Such law is geared not only to provide a framework for existing mechanisms: it is intended to pull reality towards new goals. It is innovative and directive ${ }^{76}$. Such law seeks to fulfill a programming function. It may be considered as the embodiment of programmed expectations.

\footnotetext{
73 Section Cour Constitutionnelle, Cour Suprême, arrêt d'interprétation authentique No. 3/13. 03, February 6, 1967 (not published). See T. G. VERHELST, La législation rwandaise . ., op. cit., p. 128.

74 The term was first employed to describe the unsuccessful attempts of the Dutch to introduce a model civil code in the East Indies in 1920. Prof. A. SCHILLER used the expression to refer to the new codes of Ethiopia and the Malagasy Republic: A. SCHILLER, "The Changes And Adjustments Which Should Be Brought To The Present Systems Of The Countries of Africa To Permit Them To Respond More Effectively To the New Requirements Of The Development Of The Countris", in A. TUNC, pond More Effectively To the New Requirements Of The Development Of The Countris", in A. TUNC, Paris, 1966, p. 193.

75 In developing countries, often plagued by deep and generalized weaknesses in the administrative machinery, a ceaseless determination on the part of the executive to implement the law is essential. In these "Soft States" (to use G. MYRDAL's excellent expression) there is nothing automatic about the execution of a legislative decision. On the contrary, it takes considerable effort for which very strong motivation is indispensable.

76 Prof. René DAVID is one of the most well-known advocates of the use of legislation as a programme to be gradually implemented in a developing society. See, for example, his articles "A Civil Code for Ethiopia: Considerations on the Codification of the Civil Law in African Countries", Tulane Law Review, Vol. 37, p. 187, 1963.
} 


\section{Legislation on the Judiciary in Africa: Fantasy Law or Programmed Expectations?}

\section{By T. G. Verhelst}

In Africa it is generally recognized that a high quality of the judiciary is needed in order to achieve respect for constitutional freedoms and a harmonious development. Even régimes devoted to "African Socialism" share this view, though they may question the relevance of the classic theory of separation of powers. Reality, however, seldom meets the proclaimed ideals: ignorance, bias and corruption on the part of judges, reported throughout the continent, lead to a "crisis of Justice" in Africa. Without going further into these phenomena, this paper surveys the statutory provisions on the judiciary in all independent African States and asks whether they lack the guarantees necessary for the proper functioning of a good judiciary. It deals with the quality of legal training, appointment procedures, composition of the courts, irremovability of judges, rules of professional discipline and their sanctions. African States have seriously tried to implement in their statutes the lofty principles on the Rule of Law and the role of the judiciary by means of the above-mentioned standards and techniques. The standards are met to a much higher degree by ordinary courts. Members of courts with special competences (customary or administrative courts etc.) are often less well trained in law and less independent from other powers. But on the whole African legislation generally provides satisfactory standards. The gap between the laws in the books and reality is due to the scarcity of legal manpower, the (alledged or real) needs of nation-building, budgetary constraints etc. or, more generally, to the relative impotence of legislation to forcefully model reality. One should be weary about law as a ready instrument of social engineering. But not only developing countries produce pieces of mere "fantasy laws". Some African statutes on the judiciary, however, are closer to reality in that they merely reflect existing, even if distasteful conditions and do not attempt to change them, e. g. regarding some special criminal or political tribunals. Most of these African statutes, however, may look too ambitious at present but in fact are merely ahead of their time, and have a reasonable chance of being implemented some day. They have a programming function and may be considered, hopefully, as the embodiment of programmed expectations.

\section{The International Law of Conservation of Natural Recources in Africa and the Stockholm Conference}

\section{By Albert Chedal}

The purpose of this article is to identify the attitudes of the African continent regarding the conservation of natural resources. But also the economic interests involved must be protected. The Algiers Convention (Sept. 1968) secures these interests and determines the tasks of conservation in Africa. The evolution of the position of African countries regarding the problems of conservation of natural resources evolved slowly. The 1933 London Convention, the first international instrument of this kind concerning the African continent, provided only for the 